\title{
KAUM REMNANT, SIAPAKAH MEREKA? SUATU KAJIAN BIBLIKA TERHADAP TEKS YESAYA 10:20-23
}

\author{
Ragil Kristiawan \\ (Dosen Prodi Teologi: ragil.kristiawan@gmail.com)
}

\begin{abstract}
This research seeks to find a definite identity regarding the Remnants recorded in Isaiah 10: 20-23. Various theories have been conveyed by Old Testament scholars about who the Remnants were. Some scholars conclude that the Remnants are only limited to the remnants of Assyria. Some consider that the Remnant refers to those who have returned from the Babylonian exile. In fact, some scholars consider that this also refers to future eschatological times. Through biblical studies that have been carried out with the right methodology, this research has produced a conclusion. These Prophecies of the Rest in Isaiah 10: 20-23 have multiple fulfillments. Fulfillment in its immediate context, the remnant refers to the remnants of Israel who escaped the savagery of Assyria and they later joined the Southern Kingdom. While the fulfillment in the distant context, these remnants point to a later eschatological period where God will truly gather Israel again as a nation. The distinctive feature possessed by the rest of Israel is the absolute loyalty to God (New Testament concept: Jesus Christ) and in the future there will be a fair government from God himself. From this conclusion there are also theologies and practical implications regarding the church today.
\end{abstract}

\section{A. PENDAhULUAN}

Berbicara mengenai Perjanjian Lama selalu berurusan dengan beberapa teks sulit yang perlu mendapatkan pemecahan. Hal ini terjadi karena adanya perbedaan penafsiran dari para teolog mengenai teks-teks dalam Perjanjian Lama. Kitab Yesaya tidak luput dari masalahmasalah teologis yang sedang berkembang dewasa ini mengenai isi teksnya. Salah satu permasalahan teologis yang tidak kunjung mendapatkan kebulatan suara adalah tentang kaum Remnant yang dengan jelas dituliskan secara tersurat dalam Yesaya 10:20. Teks nubuatan ini memberikan sebuah fakta penting di masa depan bahwa akan ada "sisa orang Israel dan orang yang terluput di antara kaum keturunan Yakub." Pembahasan mengenai siapakah yang dirujuk dari frasa "sisa orang Israel" tidak kunjung mendapatkan kesepakatan yang jelas dari para ahli.

Para Teolog Biblika Perjanjian Lama yang menggeluti Kitab Yesaya secara mayor mendukung pandangan bahwa kaum sisa ini menunjuk kepada orang-orang Yahudi yang akan kembali dari pembuangan Babel. Knowles dengan yakin berpandangan bahwa kelompok sisa ini adalah kelompok kecil yang kembali dari pembuangan dan kembali kepada Tuhan. ${ }^{1}$ Sekumpulan teolog yang fokus kepada penafsiran Alkitab dan menamakan diri sebagai kelompok Believer's Study Bible memberikan argumen bahwa teks Yesaya 10 ini secara khusus berisikan nubuatan tentang kejatuhan Asyur yang kemudian digenapi pada tahun 612 SM. Secara khusus kelompok ini mendefinisikan "sisa orang Israel" menunjuk kepada umat Allah yang kembali lagi ke negerinya. Umat ini akan menyembah hanya kepada Yahweh dan tidak

\footnotetext{
${ }^{1}$ Andrew Knowles, The Bible Guide, Includes Index., 1st Augsburg books ed. (Minneapolis,
} MN: Augsburg, 2001), 280. 
melakukan penyembahan kepada ilah-ilah yang lain. ${ }^{2}$ Walaupun tidak secara eksplisit menyebutkan siapakah yang dimaksud, dapat disimpulkan bahwa kelompok ini mendukung pandangan bahwa mereka ini adalah kaum yang kembali dari pembuangan Babel.

Young sebagai salah satu ekspositor Biblika Perjanjian Lama terkemuka juga tidak absen dalam membahas hal ini. Ia begitu menyoroti kesejarahan yang terjadi antara masa depan Asyur dengan Yehuda. Bagi Young, walaupun Asyur memiliki kekuasaan yang besar, ia akan mengalami akhir yang tragis oleh karena Allah. Ia menunjuk bahwa sisa orang Israel dalam bagian ini mengacu kepada umat Allah yang akan beralih kepada satu-satunya Tuhan di mana Dialah tempat yang aman untuk bersandar, yaitu Yang Kudus dari Israel. ${ }^{3}$ Young tidak memberikan penekanan dan jawaban yang khusus mengenai siapakah umat Allah ini. Ia memberikan sorotan yang lebih tajam kepada apa yang akan dilakukan oleh "sisa orang Israel ini". Wiersbe berusaha untuk melihat lebih jauh hubungan antara "sisa orang Israel" ini dengan keberadaan Mesias. Ia berkomentar bahwa ketika Asyur menaklukkan Kerajaan Utara, bangsa itu tidak pernah dipulihkan tetapi menjadi apa yang kita kenal sebagai Samaria. Setelah Penawanan Babilonia (606-586 SM), orang-orang Yehuda diberi kesempatan lagi untuk membangun diri di negeri itu; dan melalui mereka, Tuhan membawa Mesias ke dunia. Seandainya seorang yang tersisa tidak kembali, rencana Tuhan untuk menebus dunia yang hilang mungkin telah membuat frustrasi.

Secara tidak langsung Wiersbe sangat mendukung bahwa "sisa orang Israel" dalam konteks ini menunjuk kepada kembalinya orang-orang Yahudi dari pembuangan Babel dan melalui merekalah Mesias dilahirkan. Teologinya tepat. Jika merujuk kepada Kitab Hagai, "Sang cincin meterai" itu benar-benar berasal dari mereka yang kembali di pembuangan Babel. Walvoord dan Zuck memberikan penafsiran yang meluas terhadap konsep remnant dalam Roma 9 dimana menurut mereka janji-janji itu digenapi dalam Pembuangan dan Pengasingan Israel dan Yehuda serta penghancuran Yerusalem pada tahun $70 \mathrm{M} .{ }^{5}$ Bahkan mereka juga menafsirkan bahwa nubuatan kepada Kaum Remnant ini akan digenapi dalam pembebasan akhir zaman Israel secara nasional (Rm. 11:26-27). Prinsip yang sama juga berlaku. Orang-orang Yahudi yang menjadi anggota gereja, tubuh Kristus, adalah apa yang kemudian disebut oleh Paulus sebagai "seorang sisa yang dipilih oleh kasih karunia" (11:5). ${ }^{6}$

Jika diidentifikasikan, terdapat sebuah masalah penafsiran yang pelik mengenai hal ini. Peneliti menuturkan bahwa diduga terdapat permasalahan teologis di dalam Kitab Yesaya khususnya mengenai Kaum Remnant dalam Yesaya 10:20. Hal ini dibuktikan dengan identitas "sisa orang Israel" tidak kunjung mendapatkan kesepakatan yang jelas. Beberapa teolog menunjuk kepada sisa Israel yang kembali dari penawanan Babel. Bahkan ada juga yang mendukung bahwa hal ini sangat berhubungan langsung dengan Mesias yang terdapat dalam Perjanjian Baru. Pertanyaan yang diajukan dalam penelitian kali ini berkisar kepada dua hal: pertama, menunjuk kepada siapakah sebenarnya Kaum Remnant yang dimaksudkan oleh

${ }^{2}$ Believer's Study Bible, c1991 Criswell Center for Biblical Studies., electronic ed. (Nashville:

Thomas Nelson, 1997, c1995), Is 10:12.

${ }^{3}$ Edward Young, The Book of Isaiah: Volume 1, Chapters 1-18 (Grand Rapids, MI: Wm. B.

Eerdmans Publishing Co., 1965), 368.

${ }^{4}$ Warren W. Wiersbe, Be Comforted, An Old Testament study. (Wheaton, Ill.: Victor Books, 1996, c1992), Is 9:1.

${ }^{5}$ John F. Walvoord, Roy B. Zuck and Dallas Theological Seminary, The Bible Knowledge

Commentary: An Exposition of the Scriptures (Wheaton, IL: Victor Books, 1983-c1985), 2:479.

${ }^{6}$ Ibid., 480. 
Yesaya dalam Yesaya 10:20-23 ini? Kedua, teologi apa yang bisa dibangun dari Kaum Remnant dalam Yesaya 10:20-23 ini?

\section{B. METODOLOGI}

Penelitian ini termasuk dalam ranah penelitian Kualitatif Studi Biblika. Metode penelitian yang digunakan dalam penelitian ini adalah pendekatan sastra di mana hal ini meliputi hermeneutika umum dan khusus untuk memperoleh makna dari Teologi Remnant dalam Yesaya 10:20-23. Sumber data yang digunakan adalah Alkitab, Pengantar dan Survei Perjanjian Lama, Leksikon, Ensiklopedia, Kamus Alkitab, serta beberapa buku penafsiran yang relevan dengan pembahasan topik.

\section{PEMBAHASAN}

1. Pengertian "Teologi Remnant" Secara Umum

Frasa "Teologi Remnant" terdiri dari gabungan dua kata yang tidak asing bagi dunia teologi. Kata "Teologi" sendiri secara sederhana memiliki arti "perkataan-perkataan tentang Allah". Sedangkan kata "Remnant" menunjuk kepada arti "sisa". Jika kata ini dipadankan, maka secara sederhana "Teologi Remnant" berarti "perkataan atau pembelajaran tentang kaum sisa. Kamus Merriam-Webster memberikan penekanan penting tentang Remnant yaitu sebagai sebuah kelompok kecil yang masih hidup. ${ }^{7}$ Hal ini mendukung konsep "sisa" di mana kelompok orang ini masih bertahan terhadap suatu hal.

Mengenai asal-usul konsep ini pun masih menjadi perdebatan. Ada kemungkinan bahwa konsep sisa ini muncul dalam konteks eskatologi yang berasal dari mitologi Babilonia. Pandangan lain mengatakan bahwa konsep itu berawal dari lingkup sipil atau politik yang berada dalam kebijakan-kebijakan Asyur tercermin dalam prasasti tentang keberhasilan militer mereka. ${ }^{8}$ Pandangan ketiga berpendapat bahwa gagasan sisa muncul dari keprihatinan atas ancaman terhadap kelangsungan hidup manusia dan keinginan untuk menjamin kehidupan dan eksistensi dalam menghadapi kematian dalam dunia pada umumnya.

\section{Makna Teologis Kata "Remnant" dalam Perjanjian Lama}

Pembahasan tentang Remnant dalam Perjanjian Lama mencakup pembahasan yang cukup luas. Pada mulanya, konsep ini paling sering digunakan untuk menunjuk kepada Israel atau pun Yehuda (Yos. 12:4; 2 Sam. 21:2; Yes 14:30; 17:3; Am. 1:8; 9:12; Zak. 9:7). Tetapi di sisi lain, kata ini juga menunjuk kepada manusia secara keseluruhan dalam Perjanjian Lama (Zak. 14:16). Lebih luas lagi, kata ini dalam Perjanjian Lama dapat menunjuk kepada semua mahluk hidup (Kej. 7:1-5). Pemakaiannya dalam Perjanjian Lama seringkali juga memiliki konotasi negatif: malapetaka besar yang akan dialami oleh umat sehingga hanya sisa yang akan bertahan, atau tidak ada yang bertahan sama sekali (2 Raj. 21:13-15; Yes 17:4-6; Yer. 8:3; Yeh. 15:1-8; Am. 3:12; 5:3; 9:1-4).

Dalam beberapa teks Perjanjian Lama, kata ini juga sering bernuansa positif. Secara positif kata ini dapat berarti sekelompok umat yang terlepas dari kehebatan malapetaka, sisa-

${ }^{7}$ Inc Merriam-Webster, Merriam-Webster's Collegiate Dictionary., Includes Index., Eleventh ed. (Springfield, Mass.: Merriam-Webster, Inc., 2003).

${ }^{8}$ David Noel Freedman, The Anchor Yale Bible Dictionary (New York: Doubleday, 1996, c1992), 5:669. 
sisa yang dapat bertahan sebagai dasar bagi kehidupan masyarakat yang baru dan yang akan diperbaharui (Kej 8:15-19; 45:7; 1 Raj 19:18; Yes 1:25-26; 28:5-6; Yer 23:3-4; Yo. 2:32; Ob. 17; Mik. 2:12; 4:6-7). Dalam Perjanjian Lama, malapetaka dipahami sebagai tindakan penghakiman ilahi. Oleh karena itu, kelangsungan hidup dari sisa-sisa yang menjaga kehidupan yang layak tentu saja menunjuk kepada tindakan rahmat ilahi (Yer. 23:3-4; 31:7-9; Am. 5: 1415; 4: 6-7). Sementara beberapa bagian menunjukkan bahwa kaum sisa ini dapat bertahan dari kenyataan bahwa semua orang layak dihancurkan (Yer. 5; Mik. 7:18-20). Dalam catatan Perjanjian Lama, kaum sisa yang selamat digambarkan sebagai orang-orang yang benar dan setia (1 Raj. 19:18; Zef 2:3; 3: 12-13). Perjanjian Lama juga mengakui bahwa penghukuman merupakan alat pembersihan dan pemurnian dari Allah untuk memurnikan umat-Nya (Ezr. 9:1314; Yes 1:25-26; 4:2-4; 10:20).

Sedangkan orang-orang yang tersisa dipanggil untuk hidup sebagai teladan sebagai umat Tuhan. Jadi, Perjanjian Lama menganggap bahwa pengangkatan dan penyelamatan sisasisa, yang memungkinkan kelanjutan kehidupan masyarakat, dapat dipandang sebagai kegiatan menyelamatkan diri dari Yahweh (Kej. 45:7; Ezr. 9:7-9; Yes 1:9). Nabi Yesaya membawa gagasan baru mengenai remnant yaitu menunjuk kepada sisa yang akan memiliki harapan restorasi. Penghakiman ilahi akan bertindak sebagai pembersihan yang akan menyingkirkan sampah yang tidak murni. ${ }^{9}$ Perjanjian Lama tidak hanya menampilkan arti kekinian saja tentang Remnant ini. Beberapa teks menampilkan "Remnant" menunjuk kepada masa depan, dengan sisa-sisa tetap menjadi penerima tindakan keselamatan baru dan lebih besar (Yes. 11:10-16; 28:5-6; Yer. 23:3; 31:7-9; Mi. 2:12-13; 4:6-7; 5:7-8; 7:18-20; Zef. 2:7, 9). Meskipun paling sering dikaitkan dengan nabi-nabi yang terakhir, konsep tersebut muncul di beberapa bagian naratif juga.

\section{Makna Teologis Kata "Remnant" dalam Perjanjian Baru}

Perjanjian Baru juga menyinggung penggunaan kata "Remnant" dengan menekankan "kaum sisa" ini. Referensi Perjanjian Baru yang secara eksplisit membahas bagian ini terdapat dalam Roma 9-11. ${ }^{10}$ Teologi Paulus kepada orang Yahudi tersebut dibuktikan dengan kutipannya dari ayat-ayat, seperti yang terdapat dalam Yesaya 10:22; 1:9; dan 1 Raja-raja 19:18. Sewaktu Paulus berjuang dengan fakta bahwa kebanyakan orang Yahudi lainnya belum menerima Injilnya, dia mengamati bahwa "tidak semua orang yang berasal dari Israel adalah orang Israel" (Rm. 9:6b), dan bahwa "bukan anak-anak menurut daging yang adalah anak-anak Allah, tetapi anak-anak perjanjian diperhitungkan sebagai keturunan yang benar" (Rm. 9:8).

Orang-orang Yahudi yang menerima Injil-Nya merupakan orang-orang yang tertinggal. Mereka dan orang-orang kafir yang percaya telah dipilih, bukan karena kemauan atau usaha mereka sendiri, namun dengan kedaulatan dan rahmat ilahi, seperti juga nenek moyang pertama Israel yang menerima janji Allah (Rm. 9:6-33). Ini tidak berarti bahwa Israel telah kehilangan warisannya (Rm. 9:4-5) atau ditolak oleh Tuhan (Rm. 11:1-2a). Bahkan mereka yang telah dikecualikan untuk sementara waktu pada akhirnya akan disertakan juga (Rm. 11:1132). Dengan demikian, eksistensi sisa dalam kitab Roma adalah fenomena sementara, untuk

${ }^{9}$ Leland Ryken, Jim Wilhoit, Tremper Longman et al., Dictionary of Biblical Imagery (Downers Grove, IL: InterVarsity Press, 2000, c1998), 703.

${ }^{10}$ David Noel Freedman, The Anchor Yale Bible Dictionary (New York: Doubleday, 1996, c1992), 5:669. 
digantikan saat pekerjaan Tuhan selesai. Dalam Perjanjian Baru konsep Remnant masih berkisar pada orang-orang Israel yang akan memasuki kerajaan seribu tahun dengan Mesias. ${ }^{11}$

Kitab Wahyu menggambarkan situasi di gereja-gereja yang dengannya hal itu dibahas dalam istilah yang kadang-kadang mencerminkan konsep sisa (Why. 2:24; 3:4). Gambaran penggelapannya untuk menemani akhir zaman melibatkan sisa yang akan bertahan (Why. 11:13; 12:17). Dalam kitab ini, kaum Rentnant yang menang pada dasarnya mereka yang tetap beriman hingga akhir serta mematuhi perintah-perintah Allah dan memiliki kesaksian akan Yesus (Why. $12: 17 ; 14: 12 ; 19: 10) .^{12}$

\section{Eksegesis Yesaya 10:20-23}

Penentuan genre menjadi sebuah hal mutlak untuk dapat melakukan eksegesis dengan baik dari teks Yesaya ini karena eksegesis yang tepat harus sesuai dengan genre teks. Telah diketahui bersama bahwa teks Yesaya ini bergenre teks puisi. Hermeneutika terhadap puisi akan diperhatikan, dan tentu saja tidak lupa membahas mengenai beberapa kata penting yang maknanya memang penting bagi teks yang bersangkutan.

\section{a. Eksegesis Ayat 20}

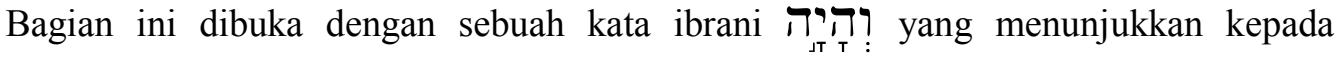
formulasi nubuatan dalam Perjanjian Lama. Sebuah kata kerja dengan awalan Vav Konsekutif yang berarti ada, menjadi, menjadi, terjadi, terjadi, harus dilakukan. Menurut kamus WSOTDICT, kata ini digunakan lebih dari 3.500 kali dalam Perjanjian Lama. ${ }^{13}$ Pada pangkal sederhana, kata kerja sering berarti menjadi, terjadi, terjadi. Ini menunjukkan bahwa sesuatu telah terjadi atau terjadi, seperti peristiwa yang telah berubah dengan cara tertentu. Acuan penggunaan ini dapat dilihat di dalam 1 Samuel 4:16 di mana imam Eli menanyakan keadaan dalam pertempuran.

Yesaya melanjutkan nubuatannya dengan memberikan perhatian pada penggunaan

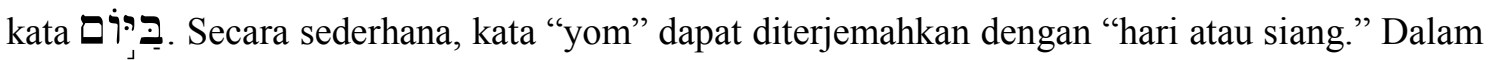
penggunaannya, kata ini memiliki varian terjemahan yang sangat beraneka ragam. Orang-orang Ibrani menggunakan kata ini untuk menunjuk kepada rentang waktu yang umum seperti yang sering diterjemahkan dengan "pada suatu hari" di dalam Kejadian 26: 8 dan juga Bilangan 20:15. Kata ini juga dapat menunjuk kepada titik waktu tertentu seperti yang terdapat dalam Kejadian 2:17; 47:29 dan juga Yehezkiel. 33:12. Dalam bentuk jamak, kata ini mungkin juga menunjuk kepada rentang kehidupan yang begitu spekulatif. Seperti yang terdapat dalam Mazmur 102:4. Kata ini juga memiliki rentang sematik untuk mengartikan satu tahun (Im. 25:29; 1 Sam. 27:7).

Jika kata ini digunakan dalam kitab nubuatan para nabi, arti konotasi sering muncul dan mewarnai pemaknaannya. Para nabi sering menggunakan dalam hubungannya dengan periode masa depan dari peristiwa-peristiwa penting seperti "hari Tuhan" yang tercatat dalam Yeremia 46:10 serta Zakharia 14: 1. Dalam kitab nabi-nabi, penggunaan frasa "Hari itu" juga

${ }^{11}$ Charles F. Pfeiffer, Howard Frederic Vos and John Rea, The Wycliffe Bible Encyclopedia (Moody Press, 1975; 2005), 394.

${ }^{12}$ Geoffrey W. Bromiley, The International Standard Bible Encyclopedia, Revised (Wm. B. Eerdmans, 1988; 2002), 4:130-134.

${ }^{13}$ Baker, Warren: The Complete Word Study Dictionary : Old Testament. Chattanooga, TN : AMG Publishers, 2003, c2002, S. 262. 
menunjuk kepada suatu masa yang sama artinya dengan "hari Tuhan". Hal ini dapat dibuktikan dari penggunaan dalam Yesaya 19:23 dan juga Zakharia 14:20, 21.

Jika merunut dalam penggunaan di Yesaya 10:20 ini, penggunaan kata hari agaknya juga penuh unsur konotasi. Peneliti berkeyakinan bahwa kata hari dalam bagian ini bukanlah menunjuk kepada satu hari tertentu. Kata hari dalam bagian ini menunjukkan sebuah kiasan mengenai suatu masa yang tidak berdasarkan kuantitas, tetapi berdasarkan kualitas dimana masa tersebut menunjuk kepada satu momen penting dalam sejarah keyahudian. William MacDonald dan Arthur Farstad menafsirkan bahwa frasa hari dalam bagian ini menunjuk kepada kedatangan kedua (dari Yesus Kristus). ${ }^{14}$ Namun penafsiran ini tidak mendapatkan dukungan dari konteks dimana konteks menunjuk kepada hari tertentu yang berhubungan dengan konteks kesejarahan pada saat itu.

Penggunaan kata yang cukup penting juga perlu mendapatkan perhatian adalah kata

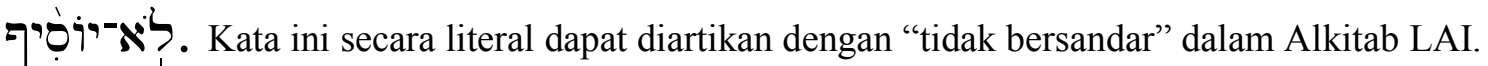
Kata ירוֹ sendiri memiliki arti meningkatkan, melakukan lagi, untuk melanjutkan. Kata ini menunjukkan suatu kegiatan yang terus dilakukan, melakukan sesuatu berulang kali, meningkatkan, menambah sesuatu, atau melakukan sesuatu setelah satu periode. Secara negatif kata ini digunakan untuk menunjuk kepada Israel yang terus melakukan dosa secara berulangulang. Dengan kegiatan tersebut, Israel semakin menambahkan (yāsap $)$ dosa yang dimilikinya serta semakin meningkatkan dosanya (Hak. 13:1; 1 Sam. 12:19; Yes. 1:5). Tetapi di sisi lain, penderitaan yang dialami oleh Israel dapat menambah sukacita atau kegembiraan mereka di dalam Tuhan (Yes. 29:19).

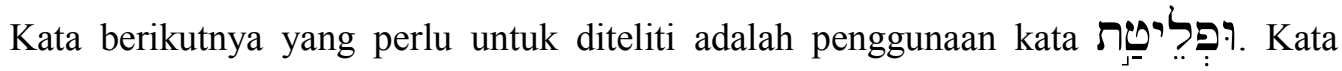
benda feminin berarti pembebasan. Penggunaannya dalam Perjanjian Lama dapat dilihat dalam Kejadian 32:8 di mana Yakub membagi kelompoknya menjadi dua kubu sehingga jika Esau menyerang satu, yang lain bisa melarikan diri. Yusuf memberi tahu saudara-saudaranya bahwa Tuhan menggunakan apa yang mereka maksudkan untuk kejahatan agar dibebaskan bagi mereka (Kej. 45:7). Musa memberi tahu Firaun bahwa belalang akan memakan apa pun yang tersisa (Kel. 10:5). Orang Israel mencari istri untuk orang-orang Benyamin yang tersisa (Hak. 21:17). Daud menyuruh semua orang melarikan diri, atau tidak ada yang selamat dari Absalom (2 Sam. 15:14). Dalam konteks Yesaya 20:10, menunjukkan kepada sisa yang terbebas dari sesuatu. Dari hal ini secara samar-samar dapat ditafsirkan bahwa hal ini menunjuk kepada penawanan di Mesir hingga mereka bisa mendapatkan kebebasan yang sejati dari Allah.

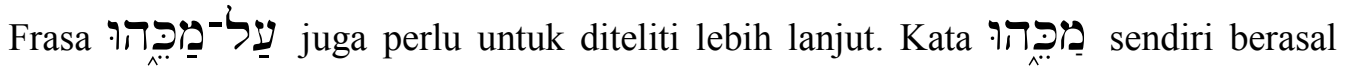
dari kata benda feminin yang dapat diartikan sebagai pukulan. Ketika kata ini diartikan secara harafiah, maka kata ini menunjuk kepada senjata seperti pedang dan cambuk dimana pukulan itu akan diberikan. Orang-orang yang dinilai salah dalam kasus hukum dapat menerima hukuman pemukulan hingga empat puluh pukulan atau cambukan (Ul. 25:3). Di tempat lain, istilah itu menandakan hasil pukulan yang menunjuk kepada sebuah luka. Raja Yoram beristirahat di Yizreel untuk pulih dari luka-luka yang terjadi dalam pertempuran melawan orang Aram (2 Raj. 9:15). Dalam pertempuran lain, Raja Ahab mati karena luka karena ditikam oleh anak panah (1 Raj. 22:35; lih. Yes 1:6; Yer. 6:7; 30:17; Mi. 1:9). Dalam bagian Perjanjian Lama yang lain, kata itu menggambarkan musibah yang ditimbulkan oleh Tuhan: kesengsaraan dan wabah.

\footnotetext{
${ }^{14}$ William MacDonald and Arthur Farstad, Believer's Bible Commentary : Old and New Testaments (Nashville: Thomas Nelson, 1997, c1995), Is 10:20.
} 
Kesimpulan yang bisa ditarik dari kata ini dalam Yesaya 10:20 adalah bahwa kata ini sejatinya berarti pukulan. Tetapi penggunaan kiasan dari kata ini juga perlu diperhatikan, bahwa penggunaan terjemahan "yang mengalahkannya" juga dapat diterima dimana hal ini menyatakan kiasan yang memang dipakai oleh Yesaya. Menanggapi ayat yang ke-20 ini, John Peter Lange, Philip Schaff, dan Carl Wilhelm Eduard Nägelsbach mengemukakan sebuah teori yang menarik. Bahwa mungkin Yesaya tidak berpikir bahwa ia telah menggunakan ungkapan "sisa Israel" tanpa arti khusus, tetapi kemudian sang nabi mengulanginya kembali dalam ayat ke-21, dengan sebuah penekanan yang lebih besar, dan pada saat yang sama mendefinisikannya lebih tepat. ${ }^{15}$

b. Eksegesis ayat 21

Pada ayat ini ada dua kata penting yang perlu mendapat perhatian khusus. Pertama adalah penggunaan bentuk konstruk dari Allah yaitu אי.. Kata bentuk konstruk ini merupakan sebuah kata benda maskulin yang berarti Tuhan, dewa, atau pun pahlawan yang kuat. Kata ini merupakan salah satu istilah paling kuno untuk menyebut Tuhan atau pun dewa. Kata ini paling sering muncul dalam Kitab Kejadian, Ayub, Mazmur, dan Yesaya. Kata ini juga bahkan tidak pernah muncul dalam beberapa kitab. Arti akar kata ini yang dapat diterjemahkan dengan "perkasa" dapat dilihat dalam Ayub 41:25 dan Mikha 2:1.

Penggunaannya dalam konteks Yesaya 10:21 menunjukkan kepada Allah Israel dengan segala keperkasaan-Nya. Kata "perkasa" dalam bagian ini menggunakan kata yang dapat diartikan sebagai perkasa dan kuat. Penggabungan kata el-gibbor biasanya diterjemahkan sebagai Allah yang Perkasa (Yes. 10:21; Yer. 32:18). Keil dan Delitzsch mengatakan bahwa kata Gibbor menunjuk kepada Allah yang secara historis diwujudkan dalam pewaris Daud (Yes. 9:6). Sementara Hosea (Hos. 3:5) menempatkan kata ini berdampingan dengan Yahweh dan Daud yang kedua. ${ }^{16}$ Dalam Yesaya juga, kata ini digunakan untuk menggambarkan Anak yang dilahirkan dan akan memerintah Kerajaan Allah sebagai Allah yang Perkasa (Yes. 9:6).

Young menyatakan bahwa di dalam ayat inilah dinyatakan kebenaran yang diajarkan atas nama anak Yesaya, Shear-Yashub. Keselamatan itu sendiri telah dijanjikan, benih wanita itu akan meremukkan kepala ular. ${ }^{17}$ Jika ini harus benar-benar digenapi, pasti ada yang tersisa yang akan meremukkan kepala ular tersebut. Israel sisa akan benar-benar kembali, dan ini adalah sisa Yakub. Ini adalah Israel sejati, umat pilihan Allah, yang akan bersandar bukan pada Asyur yang kotor, melainkan pada Allah yang Perkasa. Allah yang Perkasa ini telah diperkenalkan. Dia adalah Satu yang akan duduk di atas takhta Daud. Untuk beralih dan berbalik kepada Tuhan sendiri. "Setelah itu," kata Tuhan melalui Hosea, "akankah anak-anak Israel kembali, dan mencari TUHAN, Allah mereka, dan Daud, raja mereka; dan akan takut akan TUHAN dan kebaikannya pada zaman akhir" (Hos. 3:5).

c. Eksegesis ayat 22

Menginjak ke ayat 22, kata penting bahasa Ibrani yang perlu untuk diteliti adalah

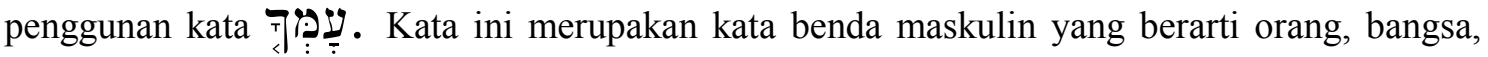

\footnotetext{
${ }^{15}$ John Peter Lange, Philip Schaff, Carl Wilhelm Eduard Nägelsbach et al., A Commentary on the Holy Scriptures: Isaiah (Bellingham, WA: Logos Research Systems, Inc., 2008), 156.

${ }^{16}$ Carl Friedrich Keil and Franz Delitzsch, Commentary on the Old Testament. (Peabody, MA: Hendrickson, 2002), 7:176-177.

${ }^{17}$ Edward Young, The Book of Isaiah: Volume 1, Chapters 1-18 (Grand Rapids, MI: Wm. B. Eerdmans Publishing Co., 1965), 368.
} 
atau pun warga negara. Kata tersebut digunakan lebih dari seribu sembilan ratus kali untuk menunjukkan sekelompok orang yang dapat dikategorikan dalam berbagai cara. Kelompok orang terbesar adalah yang terdiri dari seluruh bumi (lih. Kej. 11:1); itu terdiri dari satu orang (Kej. 11:6); yang berbagi bahasa yang sama (Kej. 11:6; Yeh. 3:5); sering juga digunakan untuk menunjuk kepada lokasi umum (Kej. 11:2). Namun, Tuhan menyebarkan kelompok dan membawa banyak bahasa, sehingga menghasilkan banyak kelompok yang kemudian akan berkembang menjadi orang-orang baru yang bersatu di sekitar bahasa universal, termasuk nenek moyang yang sama, keyakinan agama, tradisi, dan hubungan darah yang berkelanjutan.

Dalam bentuk jamak, kata itu merujuk pada banyak orang atau bangsa. Yerusalem, hancur dan meratapi, menyerukan kepada orang-orang di dunia untuk mencarinya dan kesalahannya (Rat. 1:18). Israel dipilih dari antara semua bangsa di bumi (Kel. 19:5, 7; Ul. 14:2). Tuhan mengendalikan semua rencana bangsa (Maz. 33:10). Kata ini digunakan secara paralel dengan gôyim. Ishak berdoa untuk anak-anak Yakub untuk menjadi sebuah komunitas orang-orang yang akan mencakup dua belas suku Israel (Kej. 28:3). Melihat dalam konteks ayat 22, kata ini sebaiknya diterjemahkan dengan bangsa. Tetapi bangsa yang dimaksud masihlah bangsa secara keseluruhan yang nantinya akan ditampi oleh Tuhan sendiri di pembuangan. Umat yang hatinya murni akan terus menjadi umat sisa yang nantinya akan terus mencari Allah seumur hidupnya.

Kata berikutnya yang menarik untuk diselidiki di ayat 22 ini adalah penggunaan kata הָרים Kata ini merupakan kata kerja dengan gender maskulin yang menunjukkan kepada laut. Kata ini biasanya menunjukkan batang air yang signifikan secara umum seperti yang diciptakan oleh Allah pada saat Tuhan membawa keteaturan di bumi (Kej. 1:26). Ini menunjuk pada semua air secara kolektif (Kel. 20:11); semua air yang dikumpulkan ke dalam batang air (Dan. 11:45). Kata ini sering menunjuk pada air tertentu, yang menunjuk kepada lautan: Laut Besar maupun Laut Tengah (Yos. 1:4); Lautan orang Filistin, juga Laut Tengah (Kel. 23:31); Laut Mati, secara harfiah, Laut Asin (Kej. 14:3); lautan Araba, lagi-lagi Laut Mati (2 Raj. 14:25); lautan ilalang atau Laut Merah (Kel. 10:19); lautan Mesir (Yes. 11:15); Laut Galilea (Bil. 34:11; Yos. 13:27). Ini digunakan untuk menyebut sungai-sungai besar: Nil (Yes. 18: 2); Efrat (Yer. 51:36).

Kata ini dalam Perjanjian Lama juga sering digunakan dalam frasa geografis "dari laut ke laut" (Am. 8:12). Karena sering mengacu pada Laut Tengah dan Laut Besar, pada akhirnya kata ini secara idiom berarti "barat" (Kej. 13:14); dari barat berarti di sisi barat (miyyām; Yos. 8: 9). Dengan $\bar{a} h$ ditambahkan sebagai akhiran, kata itu berarti ke arah barat (Bil. 3:23). Ini digunakan untuk model laut perunggu yang dibangun oleh Salomo dan digunakan dalam pemujaan Bait Suci (1 Raj. 7: 23-25). Kata berikutnya yang perlu mendapatkan penyelidikan adalah kata חדרוּ melukai, atau menginginkan sesuatu. Kata ini biasanya menunjukkan cacat yang dimiliki binatang yang membuatnya tidak dapat diterima untuk korban persembahan kepada Tuhan (Im. 22:22). Jika kata ini dipakai untuk mendeskripsikan hal yang dilakukan oleh anjing, maka kata ini dapat berarti menggonggong atau bergerak melawan (Kel. 11: 7). Jika digunakan untuk mendeskripsikan orang, kata ini dapat diartikan dengan berbicara secara tajam (Yos. 10:21).

Kata berikutnya adalah kata menyembur, membersihkan, menaklukkan, menenggelamkan, meluap, membanjiri, membilas, berlari, terburu-buru, membersihkan diri. Kata ini digunakan untuk menggambarkan kuasa Allah sebagai hujan lebat (Yes. 28:2). Ini juga menggambarkan suatu media yang melaluinya Tuhan memberikan hukuman kepada umat-Nya (Yer. 47:2). Tuhan menyatakan bahwa 
waktunya telah tiba untuk menghancurkan orang Filistin, dan Dia akan melakukannya, berbicara secara metafora, dengan mengangkat air ke dalam luapan yang sangat tinggi.

Yesaya menggunakan kata kerja untuk menunjukkan penghakiman ilahi terhadap Yehuda (Yes. 8:8); dan Efraim (Yes. 28:2, 15, 17, 18). Penggunaan kata ini juga bisa menunjukkan banjir atau kehancuran total di tangan bangsa lain, kadang-kadang hal ini memang terjadi karena rencana Tuhan (Yer. 47:2; Dan. 11:10, 22, 40). Penggunaan kata ini dalam konteks Yesaya 10:22 menunjuk kepada kehancuran total. LAI menterjemahkan bagian ini dengan menggunakan kata kebinasaan. Arti yang lebih cocok adalah menunjuk kepada kehancuran total. Hanya merekalah yang merupakan bagian dari kaum sisa ini yang tidak akan mendapatkan kehancuran total yang daripada Allah. Pada hari Tuhan, orang-orang Yahudi yang tersebar di seluruh dunia akan kembali ke Israel secara massal. ${ }^{18}$

Kata terakhir di ayat 22 yang perlu mendapatkan penjelasan lebih lanjut adalah kata צבר צבקה Kata ini merupakan kata benda bentuk feminin yang berarti "kebenaran, perilaku tanpa dosa, dan integritas." Kata benda ini sering menggambarkan keadilan, tindakan benar, dan sikap yang benar, seperti yang diharapkan oleh Tuhan. Dalam Perjanjian Lama, Tuhan datang untuk berbicara mengenai keadilan dan kebenaran, Dialah sesungguhnya Hakim ilahi itu (Yes. 63:1; Yer. 9:24; Mi. 7: 9). Kekudusan yang daripada Tuhan dapat dikenali oleh kebenaran-Nya dalam penghakiman yang akan dilakukan-Nya (Yes. 5:16; 10:22). Arti yang paling tepat dari penggunaan dalam Yesaya 20:22 adalah "keadilan". Kebinasaan yang dikerjakan oleh Tuhan dilakukan karena dasar keadilan-Nya. Oleh karena Ia adil, maka dosa yang tidak kunjung ada pemberesan pastilah berakibat kepada penghukuman. Keadilan akan meluap-luap, dengan artian bahwa tidak ada tempat di dunia ini bagi ketidak-adilan ketika Allah akan datang sebagai hakim yang adil.

Jamieson dan Fausset berpendapat bahwa efeknya pada "sisa" (kontras dengan sisa orang Asiria dalam Yes. 10:19); yaitu, orang-orang yang akan ditinggalkan setelah invasi Sanherib, akan kembali dari ketergantungan pada negara-negara penyembah berhala eksternal, seperti Asyur dan Mesir (2 Raj 18:21; 16: 7-9). ${ }^{19}$ Namun Israel akan segera bersandar kepada Allah yang disembah dalam teokrasi. Hal ini sebagian dipenuhi pada hari-hari Hizkia yang saleh. Fleming memberikan argumentasi bahwa Asyur hanyalah alat yang Tuhan gunakan untuk melakukan pekerjaannya, tetapi ketika alat itu mencoba untuk membuat dirinya sendiri lebih besar daripada orang yang menggunakannya, maka alat itu pun harus dihancurkan. ${ }^{20}$ Asyur akan datang kepada sebuah akhir yang memalukan. Peristiwa ini akan menjadi seperti hutan besar yang dibakar, seperti tentara yang kuat yang tumbuh, sakit dan kemudian mati.

\section{d. Eksegesis Ayat 23}

Menginjak ke ayat yang ke-23, perlu diperhatikan beberapa kata penting dan mendapatkan penekanan khusus. Kata pertama yang perlu mendapatkan penyelidikan khusus

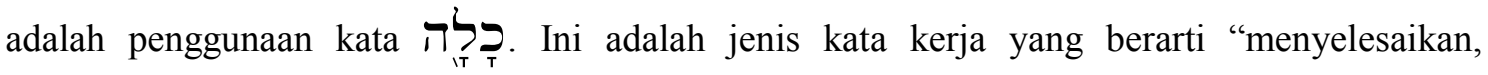

\section{${ }^{18}$ Jon Courson, Jon Courson's Application Commentary: Volume Two: Psalms-Malachi}

(Nashville, TN: Thomas Nelson, 2006), 359.

${ }^{19}$ Robert Jamieson, A. R. Fausset, A. R. Fausset et al., A Commentary, Critical and Explanatory, on the Old and New Testaments, On Spine: Critical and Explanatory Commentary. (Oak Harbor, WA: Logos Research Systems, Inc., 1997), 197.

${ }^{20}$ Donald C. Fleming, Concise Bible Commentary, Also Published Under Title: The AMG Concise Bible Commentary (Chattanooga, Tenn.: AMG Publishers, 1994, c1988), 250. 
menghancurkan, mengakhiri, dan sampai habis". ${ }^{21}$ Arti utamanya adalah untuk pencapaian hingga akhir dari suatu hal. Kata ini kadang-kadang diterjemahkan dalam arti positif seperti dalam kebaikan luar biasa dari karya Allah yang sangat baik dan selesai (Kej. 2:1,2). Kata ini juga dapat disimpulkan sebagai sesuatu yang baik dari kerja manusia seperti dalam membangun Kemah Suci (Kel. 39:32); atau menyiapkan persepuluhan (Ul. 26:12).

Namun demikian, kata ini lebih sering digunakan dengan konotasi negatif. Tuhan mengancam untuk menghancurkan ketidakpercayaan manusia (seperti dalam menyelesaikan rentang kehidupan), sebuah janji yang dipenuhi pada pemberontakan Korah (Bil. 16:21). Juga, Israel akan menjadi alat Tuhan untuk menghukum bangsa-bangsa kafir (U1. 7:22) Kata kerjanya juga menggambarkan realitas sementara dari sifat manusia yang jatuh (Mzm. 90:9), lenyap seperti awan (Ayb. 7:9). Penggunaan dalam konteks Yesaya 10:23 menyiratkan kepada akhir dari kebinasaan. Belum dapat dipastikan apakah kebinasaan disini menunjuk kepada pembuangan akhir dan perobatan dari kaum sisa Israel ataukah tidak. Yang pasti pada hari itu, kebinasaan akan terjadi bagi orang-orang yang tidak takut akan Tuhan serta kehidupan yang hanya mencari kesenangan diri sendiri.

Menurut Briley, Tuhan adalah sumber sesungguhnya dari kehancuran yang kemudian akan menghasilkan pembentukan sisa yang taat di ayat 23. ${ }^{22}$ Perlu diperhatikan juga bahwa Dialah satu-satunya harapan bagi kelangsungan hidup dan pemulihan yang tersisa. Yesaya menggambarkan masa depan di mana orang-orang yang tersisa tidak akan lagi bergantung pada yang memukul mereka. Perlakuan kejam terhadap Yehuda oleh bangsa Asyur, serta kejatuhan orang-orang Asyur berikutnya, akan mengungkap kebodohan upaya Ahas untuk mencari perlindungan di dalamnya. Setiap basis keyakinan manusia tidak stabil, tetapi Tuhan selalu dapat diandalkan. Tujuan Asyur ketika menyerang Israel adalah kehancuran total. Aspek pemulihan yang dikerjakan Allah juga perlu mendapatkan perhatian dalam bagian ini.

\section{KESIMPULAN}

Peran dari kesimpulan adalah usaha untuk menjawab pertanyaan penelitian seperti yang telah diajukan. Adapun pertanyaan penelitian yang dimaksud adalah pertama, menunjuk kepada siapakah sebenarnya Kaum Remnant yang dimaksudkan oleh Yesaya dalam Yesaya 10:20-23 ini? Kedua, teologi apa yang bisa dibangun dari Kaum Remnant dalam Yesaya 10:2023 ini dan serta implikasinya bagi gereja Tuhan masa kini?

1. Identitas Kaum Remnant dalam Yesaya 10:20-23

Berkenaan dengan identitas Kaum Remnant ini, tidak mudah memutuskan mengenai siapakah yang dimaksudkan oleh Yesaya. Menurut peneliti, setidak-tidaknya ada dua bagian besar yang dapat digunakan untuk menafsirkan mengenai siapakah yang dimaksud sebagai "kaum sisa" di dalam bagian ini. Dua prinsip yang dapat digunakan untuk menafsirkan bagian ini, yaitu prinsip kontekstual dan juga prinsip orakel kenabian yang memang secara khusus digunakan oleh Yesaya. Berkenaan dengan prinsip kontekstual, prinsip ini bermaksud untuk

${ }^{21}$ George Buchanan Gray, A Critical and Exegetical Commentary on the Book of Isaiah, IXXXIX, Series Title in Part Also at Head of T.-P.; Commentary on Chapters I-XXVII Only; the Commentary on Chapters XXVIII-XXXIX Which Had Been Assigned to G. B. Gray and on Chapters XL-LXVI Which Had Been Assigned to A. S. Peake Was Not Completed. (New York: C. Scribner's Sons, 1912), 203.

${ }^{22}$ Terry R. Briley, Isaiah, The College Press NIV commentary. (Joplin, MO: College Press Pub., 2000-c2004), 152. 
mengetahui makna sebuah frasa dengan menggunakan konteks sebelum dan sesudah dari teks yang dipelajari. Praduga mendasarnya adalah bahwa sebuah teks tidak mungkin bisa berdiri sendiri tanpa adanya konteks yang menyertai. Konteks (baik sebelum maupun sesudah) sangat memegang kunci penting bagi pemahaman menyeluruh atas sebuah teks.

Konteks sebelum dalam bagian ini menceritakan tentang Asyur, di mana bangsa ini mendapatkan predikat sebagai "cambuk murka-Ku dan yang menjadi tongkat amarah-Ku!" (Yes 10:5). Rupanya dalam bagian ini, Allah akan menjadikan Asyur sebagai alat-Nya untuk menghukum umat. Di sisi lain, Asyur yang hanyalah sebagai "alat" tersebut menjadi sombong oleh karena kemenangan-kemenangan yang dialami. Sebagai balasannya, Allah sendiri yang akan menghukum perbuatan tinggi hati yang dilakukan oleh Asyur (Yes. 10:12). Satu hal yang menarik jika memperhatikan teks dalam pasal 10 secara keseluruhan, Nabi Yesaya membawa sebuah pesan penting bahwa dibalik penghakiman atas Asyur, disanalah terletak pemulihan bagi Israel. Tidak untuk selamanya Allah akan menghukum umat-Nya. Allah yang disembah oleh Israel adalah Allah yang memegang perjanjian yang diucapkan-Nya kepada Abraham, Ishak, dan Yakub. Allah tidak mungkin akan membinasakan Israel karena Ia sendiri telah mengikat janji setia kepada umat-Nya.

Frasa menarik yang perlu mendapat perhatian khusus adalah pada pembukaan ayat yang ke-20, dimana sang nabi memberikan keterangan waktu yang khas, "pada waktu itu." Pertanyaan yang serius harus diberikan: waktu manakah yang dimaksudkan dalam teks ini? Rupa-rupanya konteks sebelum memberikan jawaban yang gamblang. Waktu ini menunjuk kepada pemusnahan Asyur oleh karena kesombongan mereka. Tuhan sendiri - dengan pertanyaan retoris-Nya - telah mendaftarkan kesalahan Asyur sehingga pemusnahan adalah semata-mata karena keadilan ilahi-Nya (ay. 15). Allah telah merancangkan pembalasan bagi Asyur, dimana Ia akan membuat "orang-orangnya yang tegap menjadi kurus kering, dan segala kekayaannya akan dibakar habis dengan api yang menyala-nyala" (ay. 16).

Bukan hanya itu saja, Allah sendiri berjanji bahwa kemegahan Asyur akan luluh lantah dimana "Keindahan hutan Asyur dan kebun buah-buahannya akan dihabiskan-Nya, dari batangnya sampai rantingnya, sehingga akan menjadi seperti seorang sakit yang merana sampai mati" (ay. 18). Sungguh, penghancuran total telah dinubuatkan kepada Asyur, dan Allah benarbenar menggenapi hal ini dalam sejarah dunia. Perhatian kepada konteks sesudahnya juga memberikan satu jawaban yang pasti akan kehancuran Asyur. Allah memperingatkan kepada umat-Nya untuk tidak takut kepada Asyur, karena penghukuman-Nya kepada Asyur adalah suatu hal yang pasti (ay. 25-26). Allah sendiri menubuatkan bahwa murka-Nya yang akan menyebabkan kehancuran Asyur. Sesungguhnya kehancuran Asyur sungguh tidak dapat ditolak oleh karena dosa kesombongan yang tidak dapat ditoleransi lagi.

Melihat kepada konteks sebelum dan konteks sesudah bagian ini, maka sangatlah diizinkan jika "sisa orang Israel dan orang yang terluput menunjuk kepada sisa Israel yang kembali ke tanah airnya dari penjajahan Asyur. Memang penafsiran ini bukanlah penafsiran yang populer, tetapi setidaknya pertimbangan konteks mengizinkan adanya kesimpulan ini. Memang Asyur telah melakukan kawin campur sehingga lahirlah suku bangsa Samaria. Hal ini juga yang dilihat oleh Wiersbe bahwa Kerajaan Utara tidak pernah dipulihkan, tetapi menjadi bangsa Samaria. ${ }^{23}$ Oleh sebab itulah, tidaklah mungkin jika yang dimaksudkan adalah sisa Israel dari pembuangan Asyur.

\footnotetext{
${ }^{23}$ Warren W. Wiersbe, Be Comforted, An Old Testament Study (Wheaton, Ill.: Victor Books,
} 1996, c1992), 129 
Memang benar bahwa Samaria terjadi karena adanya kawin campur antara Israel utara dengan Asyur. Tetapi juga patut diperhatikan bahwa secara pribadi lepas pribadi, ada orangorang yang secara sukarela pindah ke Selatan sehingga keduabelas suku Israel tersebut masih terjaga kemurniannya. Peneliti memiliki keyakinan bahwa kembalinya sebagian dari Israel ke tanah airnya dari Asyur terjadi sesudah Niniwe jatuh ke tangan orang Babel. Jadi menurut konteks, kaum sisa ini menunjuk kepada sisa Israel yang terbebas dari Asyur dan kembali ke Sion. Prinsip orakel kenabian juga perlu mendapatkan perhatian khusus dalam bagian ini. Perhatian prinsip ini perlu mendapat pertimbangan yang matang karena adanya tiga frasa yang menunjukkan kepada hal-hal yang akan terjadi pada masa "ke-akan-an," bukan kepada "kekinian." Frasa tersebut adalah: bersandar kepada Yang Maha Kudus dan tetap setia, timbul keadilan yang meluap-luap, serta kebinasaan di atas seluruh bumi."

Permasalahan terjadi terhadap frasa pertama yaitu "bersandar kepada Yang Maha Kudus dan tetap setia." Frasa ini akan sulit dimengerti jika dihubungkan kepada Israel yang terluput dari invasi Asyur. Bangsa ini tidak pernah tetap setia terus kepada Tuhan hingga sekarang ini. Bahkan setelah sebuah peristiwa besar dalam sejarah mereka yaitu pengembalian dari Babel, kesetiaan bangsa ini kepada Allah pun tidak bertahan lama. Mereka kembali melakukan dosa di hadapan Tuhan dan hal ini pun menunjuk kepada ketidaksetiaan mereka terhadap Allah Israel. Pemenuhan secara mutlak bahwa Israel akan terus setia belum pernah terjadi dalam sejarah dunia. Nampaknya orakel kenabian ini hanya akan dipenuhi di masa eskatologis kelak.

Frasa kedua yang mendapatkan perhatian khusus dalam sejarah Israel adalah penggunaan frasa "keadilan yang meluap-luap." Maksud utama dari frasa ini adalah bahwa keadilan Allah akan tetap tegak untuk selama-lamanya. Subjek yang melakukan keadilan ini tentu saja adalah Allah sendiri, sebagai raja yang adil dan bijaksana. Tentang keadilan yang meluap-luap ini juga belum pernah terjadi secara literal dalam kehidupan Israel. Tema tentang keadilan ini pernah dipertanyakan oleh Nabi Habakuk dimana ia berkata kepada Allah tentang ketidakadilan yang berkembang biak di negeri itu. Nampaknya tema tentang keadilan yang meluap-luap juga menunjuk kepada masa eskatologis kelak.

Frasa ketiga adalah tentang kebinasaan di atas seluruh bumi. Sang nabi memperluas cakrawala nubuatannya tidak berhenti kepada keadaan Israel masa kini saja. Nubuatannya diperluas hingga kepada aspek eskatologis yaitu kebinasaan atas seluruh bumi. Tema tentang kebinasaan seluruh bumi pastilah menunjuk kepada masa eskatologis ketika keadilan Tuhan dinyatakan. Dalam bahasa lain yang digunakan oleh nabi-nabi, para nabi sering menunjuk tentang hal ini sebagai Hari Tuhan. Tema tentang Hari Tuhan merupakan tema mayor yang dibawa oleh Zefanya. Kesimpulan akhirnya, Zefanya menunjuk kepada masa yang akan datang mengenai pemusnahan bumi secara total. Demikian pula jika tema ini dihubungkan dengan nubuatan Yesaya, maka kebinasaan atas seluruh bumi menunjuk juga kepada masa eskatologis kelak.

Apa hubungan dari ketiga frasa ini dengan identitas "kaum sisa?" jika yang dimaksud dalam beberapa frasa menunjuk kepada masa eskatologis, maka kaum sisa ini juga bernuansa eskatologis. Tidak dijelaskan secara pasti apakah kaum sisa ini menunjuk kepada Gereja dalam Perjanjian Baru ataukah tidak. Kemungkinan terbesar adalah hal ini menunjuk kepada Israel yang akan disatukan Allah kembali melalui kaum sisa yang nantinya akan memenuhi masa eskatologis kelak. Jadi jika dilihat dalam orakel kenabian, kaum sisa ini menunjuk kepada masa eskatologis kelak dalam sejarah dunia. Mereka yang termasuk dalam kaum sisa ini adalah orang-orang yang tetap menjaga kesetiannya kepada Tuhan hingga pada akhirnya.

Kesimpulan akhir peneliti dari bagian ini adalah bahwa nubuatan tentang kaum sisa 
dalam Yesaya 10:20-23 ini memiliki penggenapan berganda. Penggenapan dalam konteks dekatnya, kaum sisa menunjuk kepada sisa Israel yang terluput dari kebiadaban Asyur dan mereka kemudian bergabung dengan Kerajaan Selatan. Oleh karena kaum sisa inilah, maka jumlah suku di Israel tetap terjaga 12 suku. Andaikata tidak ada kaum sisa ini, maka Israel hanya memiliki 2 suku saja yang masih bertahan, yaitu Yehuda dan Benyamin.

Sedangkan penggenapan dalam konteks jauhnya, kaum sisa ini menunjuk kepada masa eskatologis kelak dimana Tuhan akan benar-benar mengumpulkan Israel kembali sebagai satu bangsa. Ciri khas yang dimiliki oleh Israel sisa ini adalah adanya kesetiaan yang mutlak kepada Tuhan (konsep Perjanjian Baru: Yesus Kristus) dan di masa depan tersebut aka nada pemerintahan yang adil dari Allah sendiri. Kemungkinan besar masa yang dimaksud adalah menunjuk kepada masa seribu tahun damai seperti yang diceritakan dalam Wahyu 20:1-6. Dalam masa inilah Yesus Kristus akan memerintah secara adil dan bijaksana. Sisa Israel yang dari mulutnya muncul pengakuan bahwa Yesus Kristus adalah Tuhan dan Juru Selamat, akan masuk ke dalam kerajaan milenium damai ini.

2. Teologi yang Dapat Dibangun dari Kaum Remnant dalam Yesaya 10:20-23 serta Implikasinya bagi Gereja Tuhan Masa Kini

Sebuah pembelajaran Alkitab haruslah menghasilkan teologi yang dapat diaplikasikan. Secara tipologi, gereja dalam Perjanjian Baru dapat juga disebut sebagai remnant, dimana "sisa dari dunia yang jahat ini" telah dipisahkan dari dunia dan bersatu dalam lembaga gereja, di mana darah Kristus di kayu salib menjadi aspek pemersatunya. Dengan demikian, teologi yang dibangun dari Kaum Remnant ini juga dapat diimplikasikan dalam kehidupan gereja saat ini. Adapun beberapa teologi serta implikasinya adalah sebagai berikut.

Pertama, Allah setia terhadap janji-Nya. Teologi ini begitu nyata dalam kehidupan Kaum Remnant. Sebelumnya telah dinubuatkan bahwa Kaum Remnant akan kembali, dan pengembalian ini benar-benar terjadi. Hal ini juga berkenaan dengan salah satu perjanjian sentral dengan Abraham, di mana Allah sendiri akan membuat sebuah bangsa yang besar baginya. Jika seandainya Allah memusnahkan semua orang Israel, tentu saja Allah menyalahi apa yang telah diucapkan-Nya sendiri. Keberadaan Kaum Remnant terjadi oleh karena Allah yang telah berjanji, dan Ia setia terhadap perjanjian-Nya itu.

Kedua, Allah adalah pribadi yang meluputkan. Teks dengan jelas menyebutkan bahwa Allahlah yang menjadi subjek atas terluputnya kaum sisa dari kekejaman Asyur. Dengan perkataan lain, Allah dan kuasa-Nyalah yang telah menyelamatkan kaum sisa tersebut. Implikasi penting bagi gereja yaitu bahwa kehidupan gereja ada karena Allah sendiri yang menjaga gereja-Nya. Bahkan Yesus sendiri berjanji bahwa "alam maut tidak akan menguasainya." Dalam sejarah Gereja, keberadaan Gereja yang Am selalu menjadi sasaran pembinasaan. Tetapi hanya oleh kuasa Allahlah, Ia berhasil meluputkan Gereja milik-Nya dari segala macam keluputan itu.

Ketiga, keselamatan bukanlah sesuatu yang bersifat kolektif, tetapi individual. Hal ini yang menjadi penekanan dalam teks Yesaya mengenai keberadaan kaum sisa. Dengan jelas teks berkata bahwa tidak semua orang Israel akan terluput. Bahkan, sebagian besar orang Israel akan mengalami kekalahan di Asyur oleh karena dosa mereka. Kejelasan sebagai garis keturunan Abraham tidak menjamin keselamatan mereka.

Tema yang sama juga menjadi tema sentral bagi soteriologi gereja. Perjanjian Baru jelas menekankan bahwa keselamatan adalah respons terhadap Kristus, bukannya sesuatu yang bersifat kolektif. Teks tua dalam Perjanjian Baru mengatakan bahwa "Percayalah kepada Tuhan Yesus Kristus dan engkau akan selamat" (Kis. 16:31). 
Keempat, bersandar total kepada Tuhan adalah ciri khas mutlak yang tidak dapat disangkal. Kaum Remnant memiliki ciri-ciri yang membedakan dengan umat yang lainnya. Mereka sangat menekankan akan keberserahan total kepada Tuhan. Jika mereka masih mengharapkan pertolongan dari bangsa-bangsa lain, maka sejatinya mereka bukanlah Kaum Remnant. Dapat dikatakan bahwa pengakuan total kepada teokrasi Allah merupakan sebuah pengakuan total sebagai bukti ke-remnant-an mereka. Gereja sebagai milik Kristus juga memiliki ciri khas ini. Anggota tubuh Kristus haruslah memiliki penyerahan total kepada Kepala Gereja atau Yesus Kristus. Sikap berserah inilah yang sejatinya menjadi ciri anak-anak Tuhan yang membedakan mereka dari dunia. Sekali lagi, Kaum Remnant menjadi tipologi bagi gereja dalam Perjanjian Baru.

Kelima, pertobatan sejati adalah sebuah tuntutan yang tidak boleh ditolak. Kaum Remnant adalah kaum yang bertobat. Mereka telah bertobat dari dosa yang selama ini membelenggu. Tanpa pertobatan, tidak mungkin disebut sebagai anggota Kaum Remnant sejati. Demikian pula dengan gereja. Anggota gereja sangatlah dituntut untuk memiliki pertobatan sejati. Dalam perspektif Perjanjian Baru, pertobatan ini disebut dengan perpalingan.

Keenam, ciri khas keadilan akan mewarnai pemerintahan Allah atas Kaum Remnant dan gereja. Kaum Remnant sangat mengharapkan akan pemerintahan yang adil dari Allah. Allah sendiri berjanji bahwa pemerintahan akan Kaum Remnant berisi dengan keadilan yang daripada Allah. Pada saat ini, gereja juga mengharapkan pemerintahan yang adil. Pemerintahan dunia sangatlah tidak adil, tetapi tuntutan Allah kepada mereka adalah tetap memberikan penghormatan penuh. Pada akhirnya pemerintahan yang bercirikan keadilan ini akan terjadi pada masa seribu tahun damai di kekekalan. 


\section{DAFTAR PUSTAKA}

Achtemeier, Paul J. Publishers Harper \& Row and Society of Biblical Literature. Harper's Bible Dictionary. San Francisco: Harper \& Row, 1985.

Baker, Warren. The Complete Word Study Dictionary : Old Testament. Chattanooga, TN : AMG Publishers, 2003.

Briley, Terry R. Isaiah, The College Press NIV commentary. Joplin, MO: College Press Pub., 2000.

Bromiley, Geoffrey W. The International Standard Bible Encyclopedia, Revised . Wm. B. Eerdmans, 1988; 2002.

Calvin, John. Calvin's Commentaries: Isaiah, electronic ed., Logos Library System; Calvin's Commentaries. Albany, OR: Ages Software, 1998.

Courson, Jon. Jon Courson's Application Commentary: Volume Two: Psalms-Malachi. Nashville, TN: Thomas Nelson, 2006, 359.

Fleming, Donald C. Concise Bible Commentary. Chattanooga, Tenn.: AMG Publishers, 1994.

Freedman, David Noel. The Anchor Yale Bible Dictionary. New York: Doubleday, 1996.

Gray,George Buchanan. A Critical and Exegetical Commentary on the Book of Isaiah, I-XXXIX, Series Title in Part Also at Head of T.-P.; Commentary on Chapters I-XXVII Only; the Commentary on Chapters XXVIII-XXXIX Which Had Been Assigned to G. B. Gray and on Chapters XL-LXVI Which Had Been Assigned to A. S. Peake Was Not Completed. New York: C. Scribner's Sons, 1912.

Inc Merriam-Webster, Merriam-Webster's Collegiate Dictionary., Includes Index., Eleventh ed. Springfield, Mass.: Merriam-Webster, Inc., 2003.

Jamieson, Robert. A. R. Fausset, A. R. Fausset et al. A Commentary, Critical and Explanatory, on the Old and New Testaments. On Spine: Critical and Explanatory Commentary. Oak Harbor, WA: Logos Research Systems, Inc., 1997.

Keil, Carl Friedrich and Franz Delitzsch. Commentary on the Old Testament. Peabody, MA: Hendrickson, 2002.

Knowles, Andrew. The Bible Guide, Includes Index., 1st Augsburg books ed. Minneapolis, MN: Augsburg, 2001

Lange, John Peter. Philip Schaff, Carl Wilhelm Eduard Nägelsbach et al., A Commentary on the Holy Scriptures: Isaiah. Bellingham, WA: Logos Research Systems, Inc., 2008.

MacDonald, William. and Arthur Farstad. Believer's Bible Commentary : Old and New Testaments. Nashville: Thomas Nelson, 1997.

Patzia, Arthur G. and Anthony J. Petrotta. Pocket Dictionary of Biblical Studies. Downers Grove, Ill.: InterVarsity Press, 2002.

Pfeiffer, Charles F. Howard Frederic Vos and John Rea. The Wycliffe Bible Encyclopedia. Moody Press, 2005.

Ryken, Leland. Jim Wilhoit, Tremper Longman et al., Dictionary of Biblical Imagery. Downers Grove, IL: InterVarsity Press, 2000.

Sawyer, John F. A. Isaiah : Volume 1, The Daily study Bible series. Louisville: Westminster John Knox Press, 2001.

Walvoord, John F. Roy B. Zuck and Dallas Theological Seminary, The Bible Knowledge Commentary: An Exposition of the Scriptures. Wheaton, IL: Victor Books, 1983.

Wiersbe, Warren W. Be Comforted. An Old Testament study. Wheaton, Ill.: Victor Books, 1996.

Young, Edward. The Book of Isaiah: Volume 1, Chapters 1-18. Grand Rapids, MI: Wm. B. Eerdmans Publishing Co., 1965 